Utah State University

DigitalCommons@USU

The Bark Beetles, Fuels, and Fire Bibliography

Quinney Natural Resources Research Library,

S.J. and Jessie E.

1987

\title{
Parasites, Lightning, and the Vegetation Mosaic in Wilderness Landscapes
}

Dennis H. Knight

Follow this and additional works at: https://digitalcommons.usu.edu/barkbeetles

Part of the Ecology and Evolutionary Biology Commons, Entomology Commons, Forest Biology Commons, Forest Management Commons, and the Wood Science and Pulp, Paper Technology Commons

\section{Recommended Citation}

Knight, D. (1987). Parasites, lightning, and the vegetation mosaic in wilderness landscapes, pp. 59-83 in MG Turner (ed) Landscape Heterogeneity and Disturbance. Springer-Verlag, New York.

This Contribution to Book is brought to you for free and open access by the Quinney Natural Resources Research Library, S.J. and Jessie E. at DigitalCommons@USU. It has been accepted for inclusion in The Bark Beetles, Fuels, and Fire Bibliography by an authorized administrator of DigitalCommons@USU. For more information, please contact digitalcommons@usu.edu.

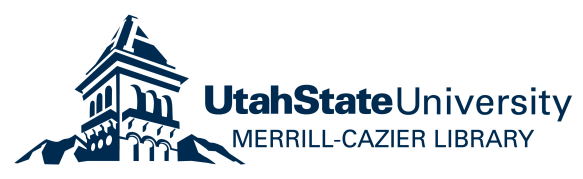




\title{
4. Parasites, Lightning, and the Vegetation Mosaic in Wilderness Landscapes
}

\author{
Dennis H. Knight
}

\subsection{Introduction}

The vegetation mosaic in any landscape is a function of environmental variation and historic disturbances, whether caused by humans or other factors. Many studies have focused on species composition in relation to environmental gradients, and secondary succession is one of the oldest themes in ecology (Fig. 4.1). Usually the study areas selected for research of this nature have been dispersed in agrourban landscapes and have included woodlots, small tracts of prairie, or other relatively small, homogeneous stands of vegetation. Although the ecological significance of the spatial positioning of the communities or patches in the agrourban matrix has been largely ignored, there seems to be a growing interest in determining how the number, variety, and juxtaposition of the patches influence the frequency and spread of disturbance as well as other landscape characteristics, including wildlife habitat, biotic diversity, nutrient retention, and productivity (Pickett and White 1985; Forman and Godron 1986).

Ecological research on landscapes, with its focus on the causes and significance of patterns beyond the scale of single stands or isolated communities, has been stimulated in part by human-caused landscape fragmentation. Over $\checkmark$ much of the earth's surface the natural mosaic is no longer visible, with "islands" of woodland or prairie interspersed in a "sea" of agriculture (Pickett and Thompson 1978; Ewel 1980). Elsewhere the natural mosaic is still apparent, but fragmentation is occurring rapidly due to timber harvesting (Harris 1984), 
A

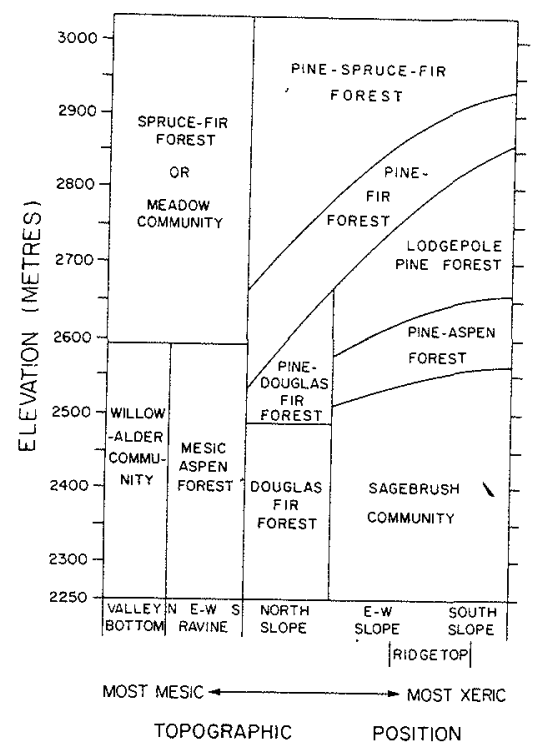

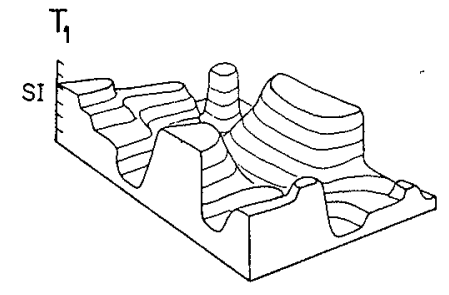
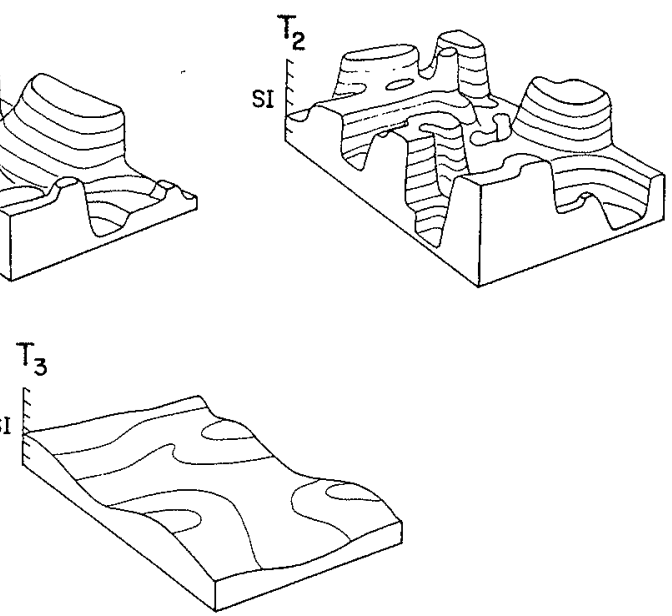

Figure 4.1. An approach for illustrating vegetation distribution (A) and vegetation dynamics (B) in landscapes. The diagram on the left, from Romme and Knight (1981), is an abstraction that shows where different vegetation types most commonly occur with regard to topographic position and elevation, but such diagrams do not portray the actual vegetation mosaic as it would appear on an aerial photograph. (B) After Pickett (1976), illustrates the shifting mosaic concept, with $T_{1}$ portraying the vegetation mosaic at one time, $T$ at some later time, and $T_{3}$ after a major disturbance. The vertical

axis (SI) is some measure of successional development, and the other two axes are longitude and latitude. Although it illustrates very nicely the shifting mosaic concept, the diagram does not incorporate the environmental variability that always exists across landscapes. A major challenge for landscape ecologists working on wildlands is understanding the simultaneous effects of patch dynamics and environmental gradients on the nature of the vegetation mosaic. Reproduced with permission of the Ecological Society of America (A) and the University of Chicago Press (B). 
for example in the Amazon Basin, the Pacific Northwest, and the Rocky Mountain Region (Fig. 4.2). Questions have arisen about the significance of preserving woodlots or hedgerows adjacent to croplands, the optimal size of woodlands or clearcuts, and the economic impacts, both in the near future and in the long term, of preserving a patchy landscape compared with one that is more ho- mogeneous. Discussions focusing on these questions have ranged from early attempts to evaluate the significance of "edge" for wildlife (Leopold 1933) to more recent attempts to apply the theory of island biogeography to terrestrial landscapes (Burgess and Sharpe 1981; Harris 1984). Humankind has a significant effect on landscape pattern. In the interest of long-term natural resource management, what is the significance of the patterns that are being created? How do natural landscape mosaics compare with those created by humans, and what ecological information should landscape architects, farmers, and forest managers consider as they continue their work?

Only a few questions of this nature can be addressed in this chapter. My objective is to explore the potential effects of certain insects, fungi, and parasitic angiosperms on landscape pattern in forested wildlands, with the belief that studying such interactions can lead to the improved management of landscapes

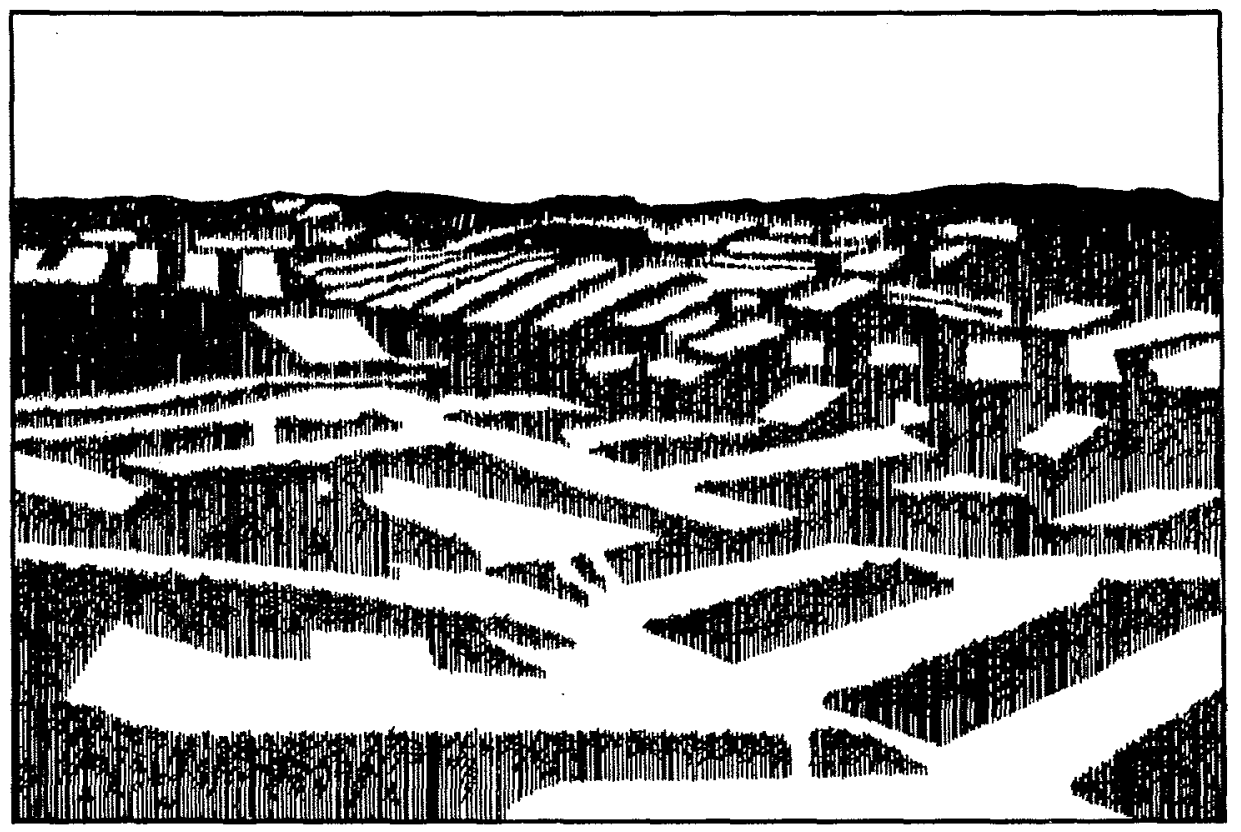

Figure 4.2. As with the original forested wildlands in other parts of the world, the forests in the western and northern parts of North America are being fragmented by timber harvesting. New landscape mosaics are being created. Whereas timber harvesting is now done more frequently in ways that minimize visual impact, is there an ecological rationale for prescribing one vegetation mosaic over another? Such questions represent a major challenge for landscape ecologists. 
in which forests are being fragmented by timber harvesting or homogenized due to fire suppression. I'll focus on parasites (sensu lato) and fire because (1) their interaction is interesting and widespread, (2) both can have significant $\checkmark$ effects on vegetation mosaics, and (3) both are often subjected to control meas-

$\checkmark$ ures. I emphasize the mosaic in wildlands because wilderness landscapes were the setting for the evolution of our biota and are changing due to human influences. Understanding the causes and significance of the vegetation mosaic in wildlands may help in the design of domesticated landscapes. Coniferous forests are emphasized because of the literature available, but brief comparisons will be made to other vegetation types.

\subsubsection{Nature of the Shifting Mosaic}

Studying wilderness landscapes presents a variety of challenges and opportunities. Unlike agrourban settings, the boundaries between the patches of the mosaic often are less regular and less contrasting (Forman and Godron 1981, 1986). Consequently, study area selection can be frustrating because the whole landscape presents so many possibilities. The actual mosaic over square kilometers or whole townships becomes interesting in itself, and the first impulse is to draw a map. Furthermore, the dynamics of the mosaic become as interesting as the dynamics of the patches (Romme and Knight 1982). Often it is not at all clear whether the border between two patches is attributable to environmental

$\checkmark$ factors or disturbances at some time in the past, and indeed, understanding the interplay of environment and history is one of the primary challenges for landscape ecologists (Pickett and White 1985). It is tempting to characterize the shifting mosaic of wilderness landscapes as being kaleidoscopic in nature, with the potential of each patch type occurring anywhere on the landscape at some time in the future, but such areas are the exception. Many factors are involved (Table 4.1) and some parts of the mosaic may change hardly at all during long periods of time (Fig. 4.3).

Fire is a very important exogenous disturbance that affects the vegetation mosaic in many areas (Wright 1974; Heinselman 1981a, 1981b; Minnich 1983; Habeck 1985; and others), and its spread is affected by a variety of factors. For example, the species composition and fuel complex may not foster the spread of a fire once started (Minnich 1983; Despain 1985). If such patches are intermingled with patches that are more flammable, the size of any particular burn may be limited. Furthermore, the site of ignition must be considered. If ignition occurs high on a slope, or just upwind of an aquatic habitat, the extent of burning may be less compared with when ignition occurs lower or some distance from natural fire breaks. The mosaic may also be affected by shifting winds, infestations of parasites that affect flammability, the degree of topographic dissection, and climatic conditions that extinguish the fire, thereby limiting its spread. Of course, factors other than fire may affect the mosaic as well (Sprugel 1976; Reiners and Lang 1979).

Fires on any particular part of the landscape are stochastic phenomena and, to some extent, are biotically controlled, (i.e., time-dependent, Heinselman 
Table 4.1. Some Factors Affecting the Spread of Fire and the Resulting Vegetation Mosaic in Wilderness Landscapes

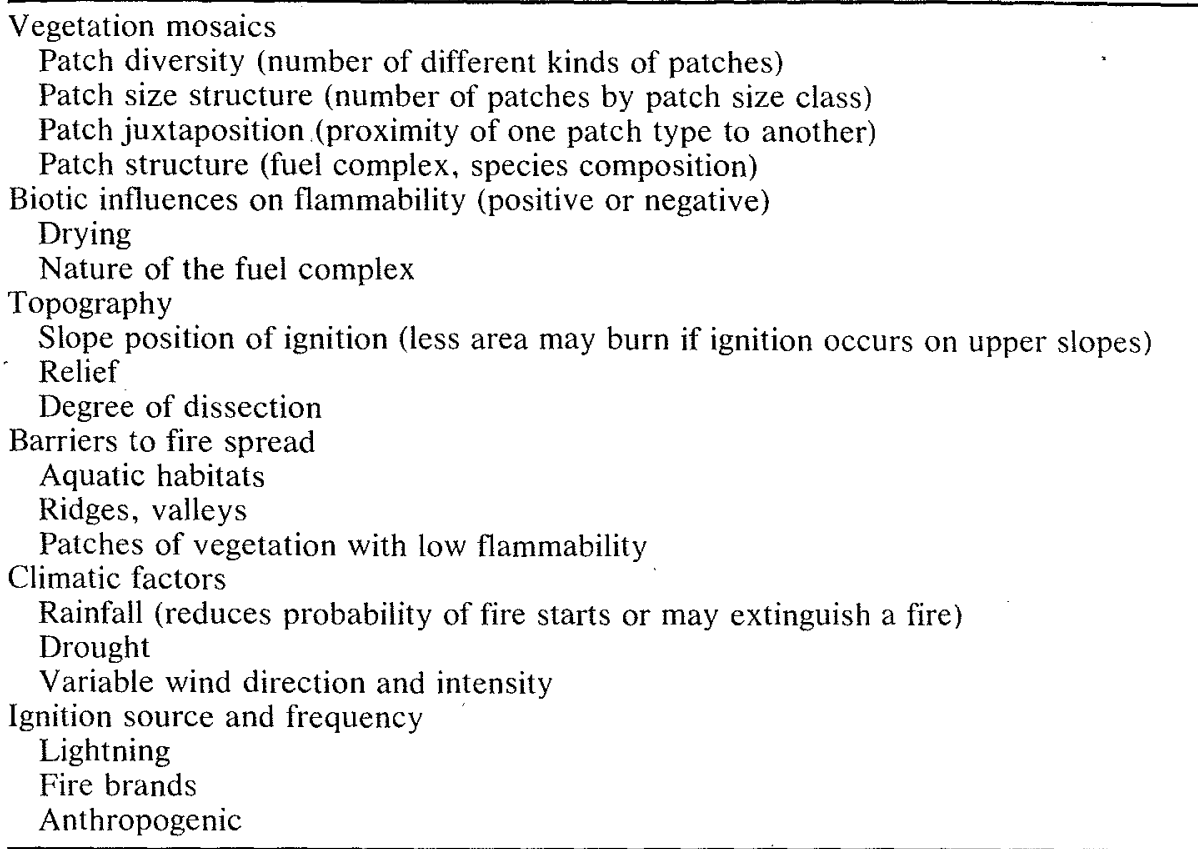

1981a, 1981b). One objective of this chapter is to consider the extent to which ignition by lightning and subsequent fire spread are affected by organisms, or, to phrase the objective in the context of the symposium theme, to determine the role of landscape heterogeneity caused by parasites (a biotic factor) in the spread of disturbance caused by lightning (a physical factor). Some of the literature that I review suggests that epidemic outbreaks of certain organisms may either increase or decrease the flammability of coniferous forests and that lightning itself may affect the pattern of parasite infestations.

As with single-stand studies, ecologists have sometimes suggested that a steady state or equilibrium condition could develop for landscapes, meaning that the proportion of the landscape in various vegetation types (or patch types) remains about the same even though the location of each type changes with time. Bormann and Likens (1981) proffered the shifting mosaic steady-state hypothesis for northeastern deciduous forest landscapes, where large catastrophic fires occur very infrequently. On the other hand, Romme (1982) found a nonequilibrium mosaic on 73 square kilometers in Yellowstone National Park characterized by large fires; studies are currently underway to determine if larger portions of Yellowstone could be viewed as having a shifting mosaic steady state (W.H. Romme and D.G. Despain, personal communication). Hemstrom and Franklin (1982) studied 530 square kilometers of forest in Mount 


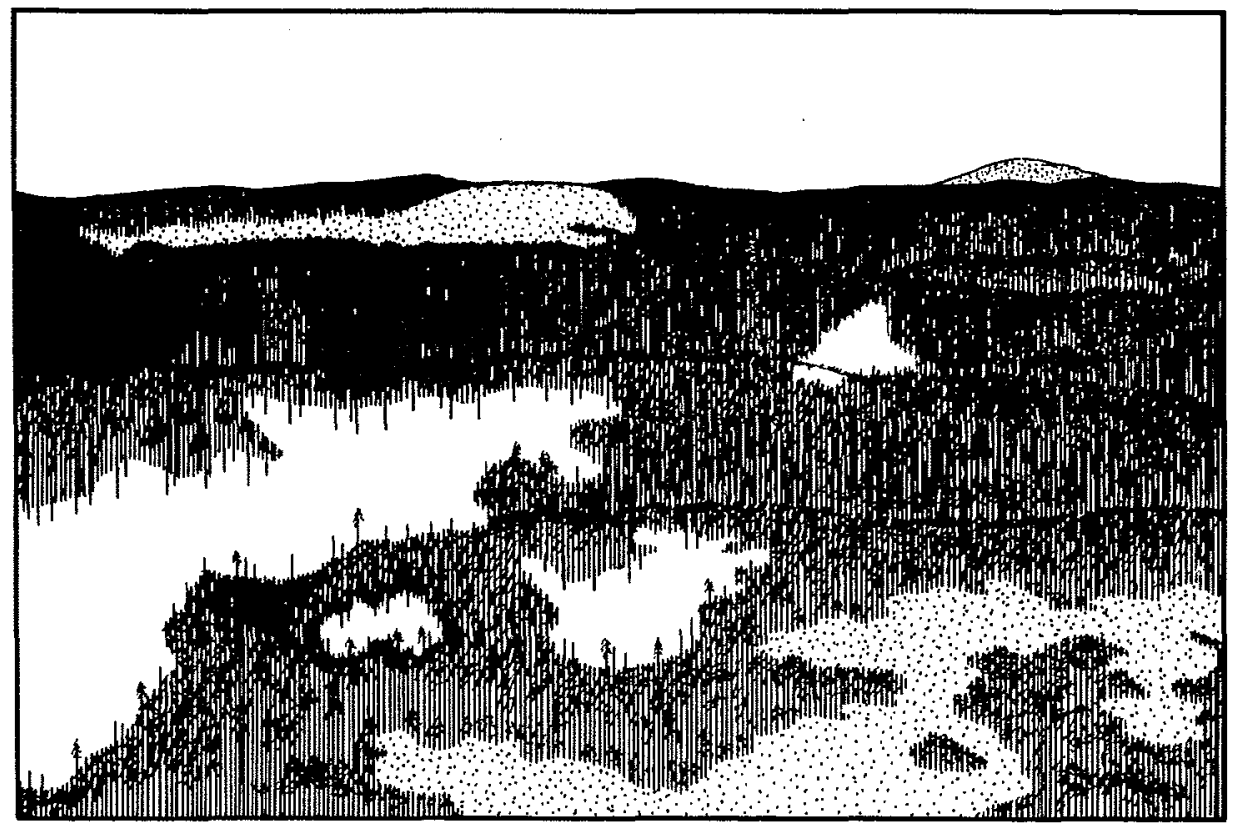

Figure 4.3. A drawing based on an aerial photograph taken in Yellowstone National Park that illustrates how fire and environmental factors combine in determining the vegetation mosaic in wilderness landscapes. The meadows, shown as stippled areas, are relatively stable in their location, occurring where edaphic conditions are less favorable for tree growth. The shape of the burned areas (white) can be attributed to a variety of factors including fuel discontinuities, the location of the lightning strike, fire brands (causing the smaller burned patches), shifting winds, and other factors such as those listed in Table 4.1. The fire burned until extinguished in the fall by rain and snow.

Rainier National Park and found no indication of an equilibrium landscape. Botkin (1980) found no a priori reason for equilibrium landscapes to occur, and paleoecological studies (Webb 1981; Davis 1981) suggest that the time scale of succession may overlap the paleoclimatological time scale more than ecologists are accustomed to admitting. Thus, the equilibrium concept may be of little value in many areas, whether for communities or landscapes.

\subsubsection{A Brief Overview of Past Research on Wildland Fire}

Of all the disturbances that affect the nature of vegetation mosaics, fire is undoubtedly the best studied. Many books have focused on the ecological effects of fire (e.g., Kozlowski and Ahlgren 1974; Mooney et al. 1981; Wein and MacLean 1983; Chandler et al. 1983; Pyne 1984; Lotan et al. 1985a), and various techniques have been devised for determining the mean return interval (Arno and Sneck 1977; Arno 1980; Swain 1980; Minnich 1983) and rate of spread 
(Rothermel 1983; Albini 1983, 1984) of fires in different regions. With regard to North American wildland fires, the reviews of Wright (1974), Kilgore (1981), and Heinselman (1981a, 1981b, 1985) are particularly noteworthy.

With few exceptions, ecological studies on fire have focused on (1) postfire successional patterns, (2) fire frequency in relation to habitat and climate, (3) plant adaptations for surviving fire or taking advantage of conditions created by fires, (4) the significance of fire suppression, (5) factors affecting the spread of fire, (6) the effects of fire on ecosystem processes, and (7) the use of fire as a management tool. All have relevance to the objectives of landscape ecology and many emphasize the role of fire in perpetuating a mosaic of community types and age classes (e.g., Rowe 1979; Forman and Boerner 1981; Heinselman 1981a, 1981b; Minnich 1983; Habeck 1985). Although most studies have been done on specific stands with relatively little attention to the significance of the mosaic or combinations of perturbations contributing to fire susceptibility, the development of regional landscape models (Johnson 1977; Kessell 1979; Romme 1982; Weinstein and Shugart 1983; Shugart and Seagle 1985), combined with significant advances in understanding flammability (Brown 1975; van Wagner 1977; Rothermel 1983; Albini 1984; van Wagtendonk 1985; Andrews 1986), have set the stage for research on fire ecology from a landscape perspective.

The gradient modeling approach of Kessell (1976a, 1976b, 1979) and his associates was one of the first landscape studies with a focus on fire. Kessell found relationships between fuel characteristics and various environmental gradients in Glacier National Park, and then conducted a detailed hectare-byhectare inventory of portions of the park, measuring the critical environmental factors in each landscape "cell." With this information accessible by computer, park managers could then predict the probability that a fire starting in one cell would spread to adjacent cells. Kessell recognized that predicting weather conditions and the potential for crowning and spotting by fire brands were problematical, but his approach illustrated a new application of traditional methodology to questions about landscapes.

Other landscape models also require dividing the terrain into cells. For example, Hett (1971), Romme (1982), and Weinstein and Shugart (1983) developed models that permitted the calculation of changes in landscape characteristics over time, for example, the percentage of the area in various successional stages. Although they provided insights into landscape dynamics, these studies did not establish the importance of patch proximity (or juxtaposition), and, as with the studies of Kessell, they did not incorporate the causes of flammability. As described below, there are a variety of processes that affect flammability and are sufficiently well understood to include in future, less empirical models that portray the dynamics of the vegetation mosaic.

\subsection{The Natural History of Flammability}

Flammability can be defined as the relative ease with which a substance ignites and sustains combustion (Wein and MacLean 1983, p. 301). Although flam- 
mability would appear to be a simple function of fuel accumulation during succession, there are various factors that must be considered to gain a more mechanistic understanding of why some areas burn more frequently or more intensely than others. This is true regardless of whether the focus is on factors affecting the spread of fire within one patch of the mosaic or from one patch to another. Great strides have been made in measuring flammability, especially fuel loadings (Brown et al. 1982), and various models exist for predicting the rate of fire spread (Rothermel 1983; Albini 1984; Andrews 1986). In this section I review some of the possible mechanisms whereby flammability increases or decreases (Fig. 4.4), particularly with regard to parasites in forest ecosystems.

Flammability is a function of drying, wind, plant species composition, the fuel complex where ignition occurs, and the fuel complex of adjacent patches of the landscape mosaic (Fig. 4.4). Each of these factors is affected in turn by others; for example, the fuel complex can become more flammable through the effects of suppression mortality, plant growth, parasites, or wind storms (Lotan et al. 1985b). Such factors can modify fuel continuity, porosity, surface/volume ratio, and dead/live biomass ratio-all of which affect flammability. One fire may reduce the probability of another (Lotan et al. 1985b), as in the case where

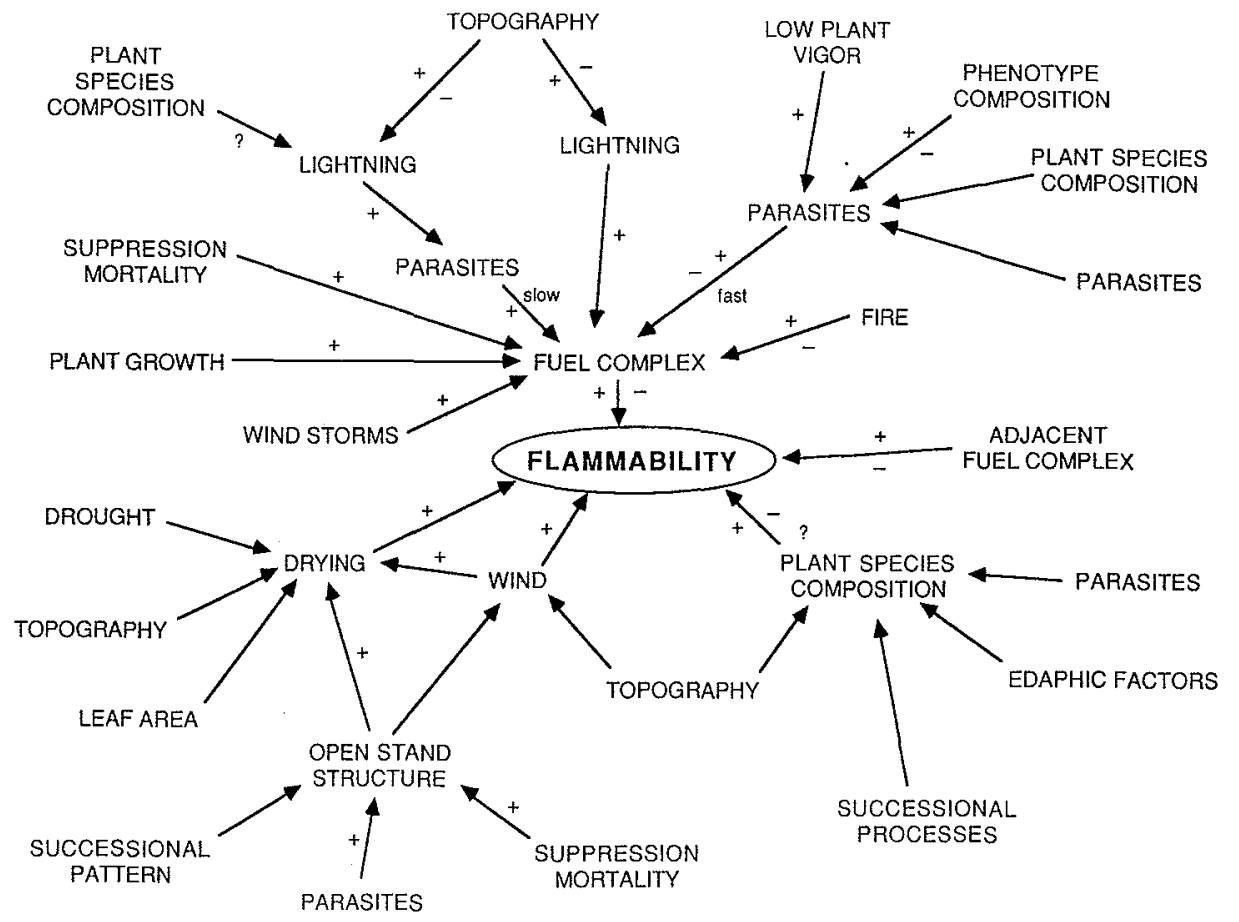

Figure 4.4. A diagram illustrating various biotic and physical factors that have positive $(+)$ or negative $(-)$ effects on flammability, as discussed in the text. Some factors are included more than once because they may contribute to the development of flammability in various ways. 
forest fuel continuity does not extend into the canopy because of frequent surface fires.

\subsubsection{Drying}

Climatic drought, microclimatic conditions caused by topography, rapid transpiration due to the development of high leaf area, a more open stand structure, or the proximity of open areas can lead to drying that greatly increases flammability if all other conditions are favorable as well (Fig. 4.4). Open stand structure can be caused by suppression mortality or wind storms, but Furyaev et al. (1983) suggested that the spruce budworm can be another important cause in the boreal forest of eastern Canada. They observed that portions of the sprucefir forest often remain quite moist throughout the year, and that flammability could increase after budworm infestations that open up the forest canopy, causing more drying of understory fuels due to more air movement and light penetration. They described a similar phenomenon caused by other insects for Siberian fir forests in the Soviet Union, and Brown (1975) suggested the potential for drying in the northern Rocky Mountains after mountain pine beetle infestations. Furyaev et al. (1983) lamented the lack of data to test their Insect-Fire Hypothesis, and acknowledged that changes in the fuel complex after infestations could be important as well. However, even if the forests would burn without the insect infestations (e.g., during infrequent drought years), the insects probably do affect the mean fire return interval as well as fire intensity, the size and shape of the area burned, and postfire successional patterns.

\subsubsection{The Fuel Complex}

Many studies have identified insects and other pathogens as important factors in increasing fuel continuity, porosity, dead/live ratios, and surface/volume ratios (Wright and Heinselman 1973; Brown 1975; Johnson and Denton 1975; Kilgore 1981; Schowalter et al. 1981, 1985; Heinselman 1983), but recent research has provided more details on the mechanisms involved, some of which are counterintuitive. For example, outbreaks of mountain pine beetle in western North America may create patches of dead trees which appear very flammable. However, a recent study (Romme, Knight, and Fedders, in preparation) found that whereas flammability may increase for a year or two while the dead leaves persist on the trees, leaf fall is quite rapid and fuel continuity in the canopy may actually decrease for 20 years or more after the infestation. The accelerated growth of understory trees (Romme et al. 1986) and the toppling of the insectkilled trees may eventually enhance flammability, but not in the initial decade as is often thought.

Other factors must be considered as well in evaluating the effect of insects on the fuel complex. Stocks (1985) studied the effect of spruce budworm outbreaks on flammability in Ontario, observing that fire spread may be restricted for a few years by the moist understory vegetation which sometimes proliferates 
after canopy defoliation. Another factor to consider in some areas may be reduced transpiration due to lower leaf area, which could preserve higher fuel moisture levels as a result of lowered rates of soil drying. Prescribed burns on the humid southeastern coastal plain have been observed to bypass patches of forest killed by the southern pine beetle, perhaps because of higher moisture content or lower concentrations of the flammable extractives in older fine fuels (T.M. Williams, personal communication).

Other insects may have similar effects, whether in terms of enhancing flammability or delaying its development, and, of course, fire suppression has been suggested as favoring conditions that lead to insect outbreaks, which in turn may enhance the probability of the next fire (Amman 1977; Peterman 1978; Schowalter et al. 1981, 1985; McCune 1983; Heinselman 1983; Waring and Schlesinger 1985; Stocks 1985). Although weather conditions favorable for hot fires may override the more subtle effects of insects, the interaction between insect outbreaks and fuel dynamics (flammability) appears to be significant. More research is needed to quantify the relationships.

Mistletoe, a common parasitic angiosperm on conifers, also affects the fuel complex, especially in terms of fuel continuity. Abnormal branching on infected trees creates living clumps of flammable fine fuels that, furthermore, serve to catch and accumulate litterfall (Hawksworth 1975; Alexander and Hawksworth 1975; Zimmerman and Laven 1984). Flammable resin-filled burls may also form (Wicker and Leaphart 1976). A fireball often results when such branches are ignited, which in turn may ignite the canopy, and flaming "witches brooms" may roll downhill or be carried aloft in convection columns, thereby causing spot fires (Alexander and Hawksworth 1975; Albini 1983). Different fuel configurations may be caused by mistletoe depending on whether the brooms are retained on the tree, as in ponderosa pine, or if they fall to the ground as in western larch and Douglas fir (Wicker and Leaphart 1976).

As with insects, fire suppression may enhance the spread of mistletoe (Wicker and Leaphart 1976; Zimmerman and Laven 1984), thereby hastening the development of conditions favorable for a larger, more intense fire. Thus far there is no indication that mistletoe increases or decreases tree susceptibility to other diseases or insects, for example, the mountain pine beetle (Hawksworth et al. 1983), but reduced tree vigor from any cause may increase susceptibility to parasitism (Berryman 1972; Raffa and Berryman 1982; Cates et al. 1983; Waring and Pitman 1983).

Trees damaged by lightning, wind, or fire may serve as epicenters for the spread of parasitism in coniferous forests, which may slowly enhance flammability (Taylor 1973; Schmid and Hinds 1974; Schowalter et al. 1981). One particularly appropriate example of such interactions was reported by Coulson et al. (1983) for the southern pine beetle. Lightning-struck trees may not ignite, and often they are not killed, but the beetles are able to locate damaged trees, probably because of increased terpene emissions (Krawielitzki et al. 1983). While ice storms and wind could also be important in creating epicenters, Coulson et al. think that lightning is the only disturbance that is sufficiently frequent to be a primary component in the evolution of the beetle's life history. In some 
parts of the beetle's range, lightning strikes may occur at the rate of 45 to 180 per square mile per year (Coulson et al. 1983).

Other studies have reported the mortality of groups of trees as a result of nonpyrogenic lightning, with the cause sometimes thought to be root rots (Taylor 1973). In addition to being epicenters for the spread of parasitism, whether by insects or fungi, wind damage may increase as gaps are created in the canopy. Flammability may increase in either case. Interestingly, Royama (1984) found no evidence for the importance of epicenters during outbreaks of the spruce budworm.

Fire itself may create favorable conditions for the perpetuation of some tree parasites, primarily because of the fire-damaged survivors that always occur. Geiszler et al. (1980) and Gara et al. (1985) concluded that fire-damaged lodgepole pine are more prone to certain fungal infections, and that these trees are more susceptible to mountain pine beetle infestation. Schowalter et al. (1981) hypothesized a similar situation with the southern pine beetle in the coniferous forests of the southeast. The beetle population reaches epidemic numbers when stand conditions are right, leading to rapid changes in the fuel complex and the eventual enhancement of flammability. The next fire creates more fire-damaged survivors, which serve as epicenters for the next wave of fungal and beetle parasitism (Fig. 4.5). Other studies also suggest how pathogens may predispose trees to beetle infestations, for example, root rots (Gara et al. 1985; Tkacz and Schmitz 1986). Various mechanisms may be involved including (1) the fungal oxidation of alpha-pinene to trans-verbenol, a beetle aggregating pheromone; or (2) the reduced vigor of infected trees, which may limit their capacity to resist insect invasion.

Fungi may also play a more direct role in the development of flammability, for example, root rot (Dickman 1984), blister rusts, and oak wilt fungi. Some depend on insects as vectors, suggesting a mutualistic relationship (for example, the case of blue stain fungi and the mountain pine beetle; Amman 1978).

Figure 4.5. An illustration of the fungus/bark beetle/fire interaction proposed by Geiszler et al. (1980) and Gara et al. (1985).

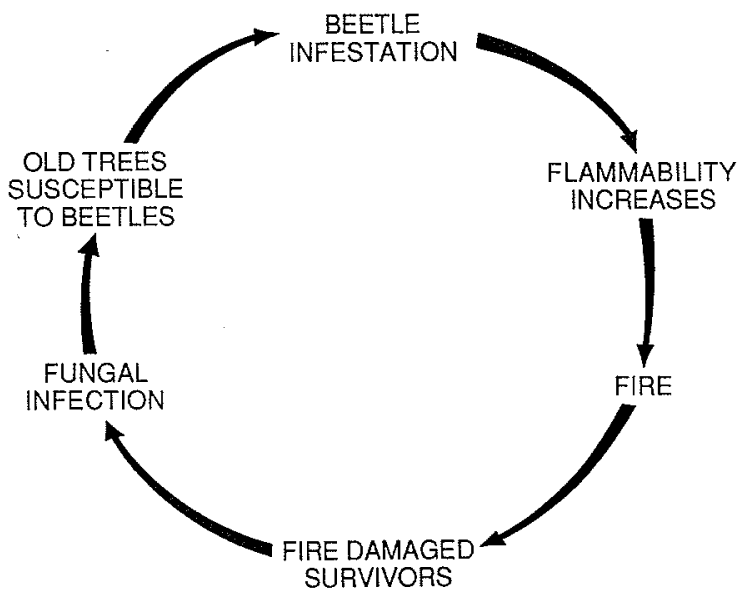




\subsubsection{Plant Species Composition}

A primary objective of many ecological studies has been to determine the factors affecting community species composition, and some of these studies are relevant to the natural history of flammability. In addition to illustrating further the effect of parasites, this research has provided evidence that certain species are more flammable than others. Thus, cycles of flammability may depend on the species composition of the live biomass as well as drying conditions, wind, and characteristics of the detritus (Fig. 4.4).

With regard to parasites, some tree species are more susceptible to infection than others. For example, the pines are much more susceptible to mistletoe than are the various species of spruce and fir, and thus mistletoe will play a role in causing flammability only when pines are common. Because the pines are usually seral species, Tinnin (1984) suggested that mistletoe tends to perpetuate conditions favorable for the persistence of pine, even to the extent of increasing the probability of the next fire, which perpetuates an abundance of the pines on which the parasite depends. Fire suppression seems to have led to an increased abundance of mistletoe (Alexander and Hawksworth 1975; Wicker and Leaphart 1976; Zimmerman and Laven 1984), and probably a more rapid development of flammability. It appears as though the spread of mistletoe serves as a feedback mechanism for perpetuating the species on which it depends. Of course, spruce-fir forests are often quite flammable, even without parasites, due to the higher fuel continuity which exists in all-aged or unevenaged stands.

Another example of differential susceptibility is the case of the spruce budworm. Balsam fir is more susceptible than white spruce, which in turn is more susceptible than black spruce. Jack pine, aspen, and birch are not susceptible. Thus, conditions favorable to the establishment of the nonsusceptible species could delay the occurrence of fire unless other mechanisms exist for accelerating flammability over and above what would be expected by biomass accumulation without perturbations. The western spruce budworm may have similar effects (J.K. Brown, personal communication), and Dickman (1984) describes a comparable example for the root rot Phellinus weirii, which infects western hemlock more readily than lodgepole pine in Oregon. With sufficient time between fires, the more susceptible hemlock may replace the pine during succession, with the root rot then accelerating the development of flammability.

Emphasis on species differences should not overshadow differences in genotypic and phenotypic variability within a species. Various investigators present evidence that some individuals of a species may be more susceptible to parasitism (Edmunds and Alstad 1978; McDonald 1981; Cates et al. 1983; Dinoor and Eshed 1984), and several studies have found that environmental conditions leading to reduced vigor will increase susceptibility (Raffa and Berryman 1982; Cates et al. 1983; Matson and Waring 1984; Waring and Pitman 1983, 1985). Such studies have great relevance to forest management programs in which pest control is desirable.

Another dimension to the effect of species composition on flammability was 
outlined with the hypothesis that some species may evolve structural or chemical characteristics that increase flammability (Mutch 1970). While ecologists usually focus on adaptations for maximizing photosynthesis or minimizing the effects of herbivory or fire, Rundel (1981) suggests that fire-dependent plants could also have evolved features that increase fire frequency. Such features include the production of more flammable tissues, the development of live tissues with a relatively low moisture content, or fuels that decay more slowly and thereby lead to a more rapid fuel buildup. Testing such hypotheses is difficult because what is perceived as an adaptation for enhancing flammability may actually be an adaptation for some other environmental stress (Christiansen 1985).

\subsubsection{The Adjacent Fuel Complex}

The susceptibility of any particular patch in the landscape mosaic to being burned is, to some degree, determined by the flammability of the adjacent fuel complex. Many have noted how flammability tends to increase with forest age, but Heinselman (1985) observed that young stands may burn as well once a major fire is underway, and Weinstein and Shugart (1983) made the assumption that when one unit of a landscape mosaic becomes highly flammable, adjacent units become more susceptible to "fire invasion." Although this is surely true to some degree, Despain and Sellers (1977) observed that forest fires in Yellowstone National Park became much less intense, or were even extinguished, when the advancing flames reached a tract of young forest with a much less flammable fuel complex. Minnich (1983) noted the same phenomenon for chaparral in California. Such observations suggest that the juxtaposition of young and old stands could reduce significantly the flammability of the landscape as a whole, a proposition commonly cited when discussing the landscape homogenization that could result from fire suppression (Minnich 1983; Habeck 1985). Heinselman (1985) suggested that the probable path of fires often can be predicted by mapping stands of old growth downwind from ignition points, which brings to mind the gradient modeling approach of Kessell (1979). Because such stands often are not large, fire spread may be restricted by stand age and/or less flammable patches of the vegetation mosaic (Despain and Sellers 1977; Romme and Knight 1982; Minnich 1983; Despain 1985). Some forest types may, in fact, function as natural fire breaks, for example, stands of red alder in the Pacific Northwest (J.F. Franklin, personal communication).

More is involved, however, than simple contrasts in forest age, and in some areas age may not be that important (Brown 1975; Lotan et al. 1985b). Heinselman (1985) and van Wagner $(1983,1985)$ suggested that young boreal forests are as flammable as older forests, and Franklin and Hemstrom (1981) noted that young forests ( 25 to 75 years) in the Pacific Northwest appear to be more flammable than older forests. Fuel continuity may be higher in younger forests, when more of the fuel is near the ground and, consequently, less heat is required to ignite the canopy. Van Wagner (1978) noted that the rate of fire spread could be highest in young stands, lowest in mature stands, and high again in very old 
stands. Thus, in boreal forests and elsewhere the proximity of young stands could greatly facilitate fire spread into old stands, or vice versa.

Fire spread to other landscape patches also can occur through spotting, that is, the wafting of "fire brands" by convective columns to some point downwind (Albini 1983; Stocks 1985; Pyne 1984). Although common, stand ignition in this manner depends more on the intensity and duration of "fire brand showers," and on in situ flammability, than on the adjacent fuel complex.

Understanding fire spread from one patch to another is central to the theme of landscape ecology, regardless of whether the goal is characterizing the flammability of the entire landscape or one patch in the mosaic. The variety of patch types and patch juxtaposition seem to be as important as the factors discussed previously which affect in situ flammability. The extent to which fire spreads from one patch to the next will depend on the contrast in fuel conditions between the two patches, with fire spread occurring until the heat generated is inadequate for the pyrolysis and ignition of additional fuel particles (as discussed below). Of course, spotting by fire brands may negate the effect of fuel discontinuities if the brands can be wafted to a more flammable patch downwind.

\subsection{The Natural History of Ignition}

Ignition of the fuel complex becomes increasingly probable as the level of flammability increases, whether due to stand age or other physical and biotic factors, and at some point a fire is initiated by lightning or humankind. Although in some areas the frequency of fire may be affected by human activities, Heinselman (1973) and van Wagner (1983, 1985) suggested that the ignition source is relatively unimportant compared with the fuel loadings and weather at the time. Others have suggested that the influence of native North Americans has been underestimated (e.g., Gruell 1985), arguing that the less extensive coverage of closed forests in presettlement times was due to more frequent anthropogenic fires. Such fires could have been caused by lightning as well, even in grasslands (Komarek 1964), but regardless of the ignition source their effect probably was to create more frequent surface fires which, in some areas, may have slowed the development of flammability. The presence of humans, and their rationale for starting fires, surely represents another biotic influence on the shifting landscape mosaic. But can the same be said for ignition by lightning? Do the biota facilitate ignition, over and above their effects on the development of flammability, and are lightning strikes affected by the biota? Information pertaining to these questions is reviewed in the following sections.

\subsubsection{Ignition}

Before combustion can occur, sufficient heat is necessary to dehydrate the fuels; initiate the pyrolysis (volatilization) of various organics, including terpenes, fats, oils, and waxes; and ignite the gases produced by pyrolysis, thereby 
creating flaming combustion (Rundel 1981; Pyne 1984). Once the fuels have been dehydrated, ignition usually occurs at 500 to $700^{\circ} \mathrm{C}$. Glowing combustion or smoldering may occur as well as flaming combustion, and is especially important because it produces more heat per gram of fuel, causes more root damage, accounts for most forest floor combustion, and provides a persistent source of ignition, for example, by sustaining the combustion of fire brands or smoldering logs (Taylor 1973; Agee 1981; Minnich 1983; Gara et al. 1984, 1986) which may be the ignition source for large fires after long delays. Fire spread will depend, of course, on the degree of flammability that has developed at the time, and will continue until fuel characteristics, oxygen, or heat fall below critical levels. The fact that these conditions are not easily maintained accounts for the observation that most forest fires burn less than a hectare (Pyne 1984).

There are various ways in which biotic influences or biotic characteristics could influence the amount of heat required for ignition. To illustrate, some plant materials do not dry as rapidly as others, due perhaps to better stomatal control or other mechanisms for maintaining water within the plant tissues (which may be a function of habitat). For example, van Wagner (1977) suggested that crown fires may not develop in aspen forest as readily as in coniferous forests because plant moisture content usually remains above $140 \%$, compared with the 70 to $130 \%$ moisture which supports crown fires in adjacent conifers. Thus, the heat required for aspen dehydration could exceed the heat generated by the ignition source. Dead forest fuels are often classified into 1-, 10-, 100-, and 1000-hour categories, a classification based on the estimated amount of time required for dehydration to a certain level when subjected to drying (Rothermel 1983; Pyne 1984).

Also, different plant species or different plant materials could produce more or less flammable gases per British thermal unit (btu). For example, decaying wood gives off gases more readily than the wood of intact trees, even if moist, and some species apparently produce more volatile organics than others (Rundel 1981). It seems plausible that parasites could facilitate the production of flammable gases.

Most ignitions in forests seem to occur first in the forest floor or litter layer, probably because the fine fuels there are more compact and continuous. Van Wagner (1977) defines the conditions under which three different kinds of crown fires can develop, noting that usually a surface fire is necessary first because the crown by itself does not generate enough heat for dehydration, pyrolysis, and combustion. Wind is important for the starting and maintenance of crown fires, as is the height above ground to a minimum fuel bulk density (the fuel ladder concept). Thus, as discussed in the context of flammability, various biotic factors can have a significant effect on whether or not a crown fire develops.

\subsubsection{Lightning}

Bolts of lightning strike the earth thousands of times every day (182 million strikes per year for the earth), but less than $1 \%$ start fires (Taylor 1973). In part this low percentage can be attributed to conditions of low flammability at 
the place and time of the strike, in particular the fact that many strikes occur during rain storms, but the nature of the lightning strike is important also. All strikes have tremendous amounts of energy, but some, the long-continuing strikes which last about $100 \mathrm{msec}$, are hotter than "fast lightning" and are of sufficient duration to increase dramatically the chances of dehydration, pyrolysis, and flaming. Such strikes have sufficient energy to rupture a live conifer, creating a "shower" of fine fuel particles which undergo pyrolysis in msec and flash into a fireball that in turn ignites other fine fuels (Taylor 1973). In western North America, where up to $70 \%$ of the fires are caused by lightning, less than $20 \%$ of the lightning strikes are of the long-continuing variety (Taylor 1973). Of course, as discussed previously, all lightning strikes may have an indirect effect on flammability by creating additional fuel or providing a favorable environment for the rapid population increase of a parasite. By various means, lightning and/or parasites alter ecosystem structure in ways that affect flammability.

But is it reasonable to think that the precise location of a lightning strike could be influenced by the biota? Are snags or certain species more susceptible to lightning strikes? The answers to such questions are inconclusive, partly because of the difficulty of obtaining data. Often the ignition point can be determined if a fire is started, but the target of nonpyrogenic lightning is very difficult to ascertain. The available data are often imprecise or circumstantial, but are worthy of consideration nevertheless.

One of the earliest studies of lightning-caused forest fires was done by Barrows (1951), who found that the "first-ignited fuels" of 11,835 fires in the northern Rocky Mountains were, in decreasing frequency, snags 34\%, duff on the ground $30 \%$, wood on the ground $12 \%$, green tree tops $10 \%$, and miscellaneous other ignition points $14 \%$. Barrows' data suggested that aerial fuels were ignited in $48 \%$ of the fires, which is higher than data reported by others (Plummer 1912) and which contradicts the theoretical conditions for a crown fire outlined by van Wagner (1977). Dead trees probably ignite more readily than live trees, and thus are more visible than lightning-struck live trees which do not ignite. Coulson et al. (1983) suggested that live, well-hydrated trees, with their roots in wet soil, should provide an electrical path of lower resistance than would a dead, dry tree, and Chapman (1950) reported that most strikes were to live trees in southeastern long-leaf pine forests, but the available information is inadequate for confident statements about the mechanisms determining the precise location.

Once started, some fires create another source of ignition, namely fire brands (Albini 1983; Pyne 1984; Stocks 1985). The "rain of fire brands" that may occur causes "spotting" downwind and can greatly magnify the effect of a single lightning strike. Furthermore, such ignitions facilitate fire spread across fuel discontinuities or other barriers.

The geography of lightning has been the subject of several studies, with the objective of determining whether some areas or forest types have a higher risk of strikes than others. Such work has involved the mapping of lightning fire zones, which Kourtz (1967) concluded do exist. One of the more detailed studies 
of this nature was that of Asleson and Fowler (Asleson 1975; Fowler and Asleson 1982; Fowler and Asleson 1984), who did a locational analysis of fires in northern Idaho. Although their data were based on fires, not strikes, their results suggested that grand fir forests, cedar-hemlock forests, and Engelmann sprucesubalpine fir forests were more likely to be ignited by lightning than would be expected based on the area each occupied. These results probably are due more to the fuel conditions that develop in these forests, or their topographic position, than to some inherent characteristic of the trees themselves. They found that, of 2087 fires, only $18 \%$ occurred below the upper two-thirds of the mountain (49\% occurred on the upper one-third). Combining various factors, they concluded that the forests with the highest risk of lightning fire were those dominated by hemlock or Engelmann spruce and subalpine fir and occurring on the upper half of slopes perpendicular to the most common storm tracks. Similar studies were done by Hemstrom (1982) and Vankat (1985) in Mount Rainier National Park and Sequoia National Park, respectively.

Every lightning strike creates radio waves which can be used to locate the strike by triangulation. This principal has been adopted by industry (e.g., Lightning Location and Protection, Inc., Tucson, Arizona) for developing instrumentation capable of producing daily "lightning maps" for large areas. For example, this technology detected 786 ground strikes over Yellowstone National Park and vicinity during a 2.5-hour period on June 27, 1986; five fires were started but none continued to burn (D.G. Despain, personal communication). A more precise analysis of lightning strikes, as opposed to lightning-caused fires, may be possible as such data sets develop.

\subsection{The Vegetation Mosaic in Nonforested Landscapes}

Most studies in landscape ecology have tended to focus on regions dominated by forests, in part because many wildlands occur in regions of coniferous forest but also because boundaries between forests of different ages persist for many years and are easily detectable. The mosaic is very obvious, whether in a wilderness or an agrourban landscape, and the pattern clearly is not a simple function of environmental gradients.

Coniferous forests in particular lend themselves well to studies on the causes and patterns of the vegetation mosaic. Stand-replacing fires characterize such areas, along with significant episodes of parasitism, and, unlike many deciduous forests or chaparral, sprouting as a means of forest regeneration is a relatively rare phenomenon. Thus, the rate of recovery may be slower than in stands that develop by sprouting and the time available for occupancy by other species may be longer (Fig. 4.6). At the opposite extreme from coniferous forests are perennial grasslands, where very little structure develops aboveground, the fuel complex is more a function of annual shoot senescence than plant death or fragmentation, and a fire does not normally kill the plants. Recovery is rapid, being simply a matter of regrowth from live root crowns or rhizomes, and op- 


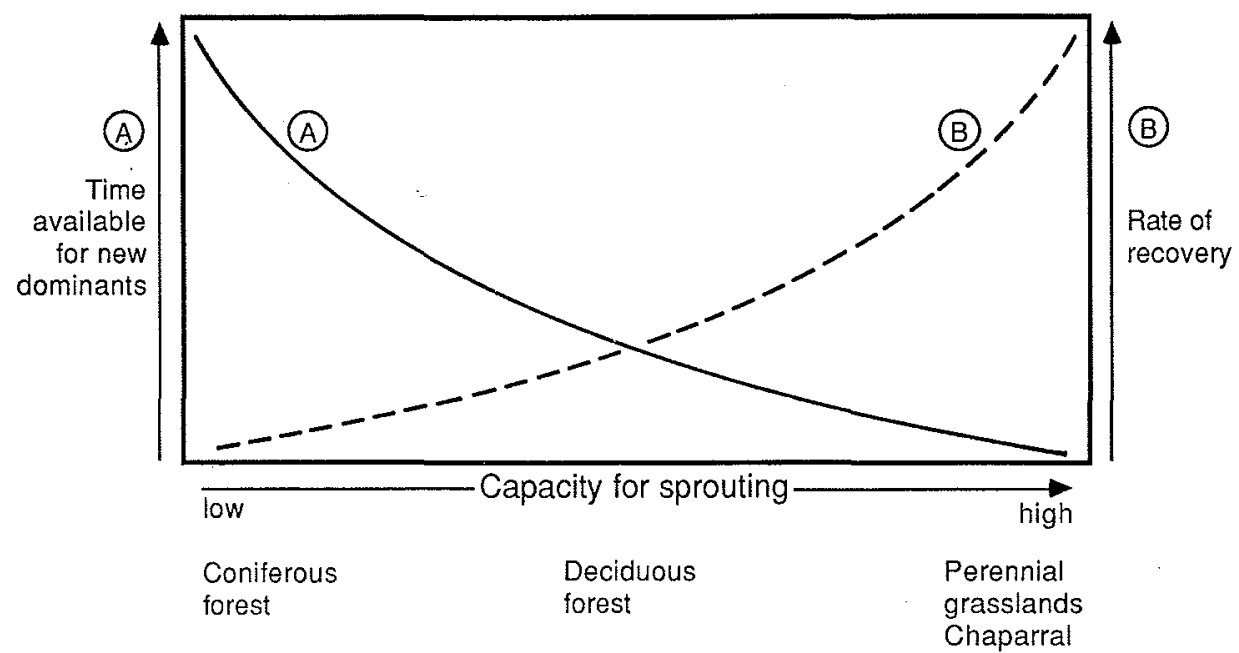

Figure 4.6. A generalized depiction of the possible relationships between the capacity for sprouting in various vegetation types, the rate of vegetation recovery after fire or some other major disturbances, and the time available after a disturbance for occupancy by new species. With some exceptions, coniferous forest mosaics may be more variable in space and time due to a lack of sprouting and relatively slow rates of patch recovery, as discussed in the text.

portunities for the invasion of pioneer species are limited. Some chapparal landscapes are very similar to grasslands in this regard, though fire frequency and the pattern of flammability development are quite different (Minnich 1983). The vegetation mosaic at the landscape scale in deserts or tundra may be affected by disturbances also, but environmental gradients probably are more influential under such rigorous climatic conditions.

Intermediate between grassland and coniferous forests are (1) deciduous forests, where some mortality may occur after fire; (2) mixed conifer-hardwood forests, where a large proportion of the stand may be killed resulting in a slower recovery; or (3) shrub-dominated grasslands such as sagebrush steppes where the shrubs may be killed by fire but most of the grasses and forbs are not. In the case of sagebrush steppe, recovery to the original composition is slower than grassland without sagebrush, but little opportunity exists for the invasion of other species (except for certain exotic species or under conditions of heavy grazing).

Vegetation mosaics caused by historical perturbations certainly must exist in landscapes dominated by deciduous forests or grasslands, where fires or other disturbances also have limits to their spread and where shifts in species composition occur at various scales including that of the landscape. Regrettably, the extensive tracts of deciduous forest, grassland, and shrubland required for such studies are difficult to find, if indeed they still exist at all. 


\subsection{Summary}

The vegetation mosaic in wilderness landscapes at any particular time is determined by a broad range of factors including environmental gradients, continuing climatic change that may foster gradual changes in species composition, elements of chance with regard to location of ignitions and barriers to fire spread, and small scale disturbances that may increase the probability of larger scale conflagrations. In this chapter I have reviewed several mechanisms whereby biotic factors interacting with physical factors (even nonpyrogenic lightning) may enhance the probability of a fire occurring sooner (or later) than it might otherwise. The mechanisms seem intuitive and logical, though many must still be viewed as hypotheses and their importance will vary with vegetation type and position in the landscape.

Although one of the major challenges for landscape ecologists interested in wildlands is to deal simultaneously with the environmental and disturbance variables that cause the nature of the vegetation mosaic, an even greater challenge is understanding the ecological significance of the mosaic. What changes occur if the mosaic becomes homogenized due to fire suppression, or if the mosaic is modified as a result of timber harvesting or prescribed burning? What is the effect of having many small, contrasting patches instead of fewer large, contrasting patches? Answers to such questions are inherently interesting because wilderness landscapes were the setting for the evolution of most organ-

isms, but also because one of the most conspicuous and universal effects of land management activities is to change vegetation mosaics. More efficient resource utilization and conservation could result when the importance and dynamics of the mosaic are understood as well as the dynamics of the patches.

Some interesting research on the significance of patch juxtaposition has already been done. For example, various studies have shown how fire spread may be retarded by a patchy vegetation mosaic (e.g., Minnich 1983; Heinselman 1985), and watershed hydrologists in the Rocky Mountains can now prescribe vegetation mosaics that maximize streamflow (Leaf 1975). Optimal mosaics for certain wildlife species also can be prescribed in some areas (Thomas et al. 1976; Harris 1984). Less information is available on the importance of the mosaic to, for example, (1) the preservation of biotic diversity; (2) maintaining a certain level of primary or secondary productivity; (3) the spread of weeds and the probability of insect epidemics or other disturbances; and (4) nutrient fluxes that could affect site productivity or streamwater quality. The results of wildland studies may be different from those for agrourban landscapes, but the insights gained could be useful to land managers everywhere.

\section{Acknowledgments}

Discussions with William H. Romme, William A. Reiners, and Don G. Despain have been very helpful, and I am grateful to the following persons for reviewing an earlier version of the manuscript: James K. Brown, Don G. Despain, Jerry 
F. Franklin, Robert I. Gara, E.A. Johnson, David A. MacLean, Steward T.A. Pickett, William H. Romme, Monica G. Turner, and Peter S. White.

\section{References}

Agee, J.K. 1981. Initial effects of prescribed fire in a climax Pinus contorta forest: Crater Lake National Park. National Park Service Report, CPSU/UW 81-3. College of Forest Resources, University of Washington, Seattle, WA.

Albini, F.A. 1983. Potential spotting distance from wind-driven surface fires. USDA, Forest Service, Research Paper INT-309.

Albini, F.A. 1984. Wildland fires. Am. Scientist 72:590-597.

Alexander, M.E., Hawksworth, F.G. 1975. Wildland fires and dwarf mistletoes: A literature review of ecology and prescribed burning. USDA, Forest Service, General Technical Report RM-14.

Amman, G.D. 1977. The role of the mountain pine beetle in lodgepole pine ecosystems: Impact on succession, pp. 3-18. In W.J. Mattson (ed.), The Role of Arthropods in Forest Ecosystems. Springer-Verlag, New York.

Amman, G.D. 1978. Biology, ecology, and causes of outbreaks of the Mountain pine beetle in lodgepole pine forests, pp. 39-53. In D.L. Kibbee, A.A. Berryman, G.D. Amman, and R.W. Stark (eds.), Theory and Practice of Mountain Pine Beetle Management in Lodgepole Pine Forests. Forest, Wildife, and Range Experiment Station, University of Idaho, Moscow, ID.

Andrews, P.L. 1986. BEHAVE: Fire behavior prediction and fuel modeling systemBurn subsystem, Part 1. USDA, Forest Service, General Technical Report INT-194.

Arno, S.F. 1980. Forest fire history in the northern Rockies. J. Forestry 78:460-465.

Arno, S.F., Sneck, K.M. 1977. A method for determining fire history in coniferous forests of the mountain west. USDA, Forest Service, Research Paper INT-202.

Asleson, D.O. 1975. Locational analysis of lightning-caused forest fires. Master's thesis, Department of Geography, University of Wyoming, Laramie, WY.

Barrows, J.S. 1951. Forest fires in the northern Rocky Mountains. USDA, Forest Service, Station Paper RM-28.

Berryman, A.A. 1972. Resistance of conifers to invasion by bark beetle-fungus associations. BioSci. 22:598-602.

Bormann, F.H., Likens, G.E. 1981. Pattern and process in a forested ecosystem. Springer-Verlag, New York.

Botkin, D.B. 1980. A grandfather clock down the staircase: Stability and disturbance in natural ecosystems, pp. 1-10. In R.H. Waring (ed.), Forests: Fresh Perspectives From Ecosystem Analysis. Proceedings of the 40th Annual Biology Colloquium. Oregon State University Press, Corvallis, OR.

Brown, J.K. 1975. Fire cycles and community dynamics in lodgepole pine forests, pp. 429-456. In D.M. Baumgartner (ed.), Management of Lodgepole Pine Ecosystems. Washington State University Cooperative Extension Service, Pullman, WA.

Brown, J.K., Oberheu, R.D., Johnston, C.M. 1982. Handbook for inventorying surface fuels and biomass in the interior west. USDA, Forest Service, General Technical Report INT-129.

Burgess, R.L., Sharpe, D.M. (eds.) 1981. Forest Island Dynamics in Man-Dominated Landscapes. Springer-Verlag, New York.

Cates, R.G., Redak, R., Henderson, C.B. 1983. Natural product defensive chemistry of Douglas fir, western spruce budworm success, and forest management practices. Z. Angew'. Entomol. 96:173-182.

Chandler, C., Cheney, P., Thomas, P., Trabaud, L., Williams, D. 1983. Fire in Forestry, Vol. 1. Forest Fire Behavior and Effects. Wiley \& Sons, New York.

Chapman, H.H. 1950. Lightning in the longleaf. J. Am. Forestry 56:10-11. 
Christiansen, N.L. 1985. Shrubland fire regimes and their evolutionary consequences, pp. 85-100. In S.T.A. Pickett and P.S. White (eds.), The Ecology of Natural Disturbance and Patch Dynamics. Academic Press, New York.

Coulson, R.N., Hennier, P.B., Flamm, R.O., Rykiel, E.J., Hu, C., Payne, T.L. 1983. The role of lightning in the epidemiology of the southern pine beetle. Z. Angew. Entomol. 96:182-193.

Davis, M.B. 1981. Quaternary history and the stability of forest communities, pp. 132153. In D.C. West, H.H. Shugart, and D.B. Botkin (eds.), Forest Succession: Concepts and Application. Springer-Verlag, New York.

Despain, D.G. 1985. Ecological implications of ignition sources in park and wilderness fire management programs, pp. 93-97. In J.E. Lotan, B.M. Kilgore, W.C. Fischer, and R.W. Mutch (technical coords.), Proceedings: Symposium and Workshop on Wilderness Fire. USDA, Forest Service, General Technical Report INT-182.

Despain, D.G., Sellers, R.E. 1977. Natural fire in Yellowstone National Park. West. Wildlands 4:20-24.

Dickman, A.W. 1984. Fire and Phellinus weirii in a mountain hemlock (Tsuga mertensiana) forest: Postfire succession and the persistence, distribution, and spread of a root-rotting fungus. Doctoral dissertation, University of Oregon, Eugene, OR.

Dinoor, A., Eshed, N. 1984. The role and importance of pathogens in natural plant communities. Ann. Rev. Phytopath. 22:443-466.

Edmunds, Jr., G.F., Alstad, D.N. 1978. Coevolution in insect herbivores and conifers. Science 199:941-945.

Ewel, J.E. 1980. Special issue on tropical succession. Biotropica 12 (suppl.):1.

Forman, R.T.T., Boerner, R.E. 1981. Fire frequency and the pine barrens of New Jersey. Bull. Torrey Botan. Club 108:34-50.

Forman, R.T.T., Godron, M. 1981. Patches and structural components for a landscape ecology. BioSci. 31:733-740.

Forman, R.T.T., Godron, M. 1986. Landscape Ecology. Wiley \& Sons, New York.

Fowler, P.M., Asleson, D.O. 1982. Spatial properties of lightning-caused forest fires. Physical Geog. 3:180-189.

Fowler, P.M., Asleson, D.O. 1984. The location of lightning-caused wildland fires, Northern Idaho. Physical Geog. 5:240-252.

Franklin, J.F., Hemstrom, M.A. 1981. Aspects of succession in the coniferous forests of the Pacific, pp. 212-229. In D.C. West, H.H. Shugart, and D.B. Botkin (eds.), Forest Succession: Concepts and Application. Springer-Verlag, New York.

Furyaev, V.V., Wein, R.W., Maclean, D.A. 1983. Fire influences in Abies-dominated forests. pp. 221-234. In R.W. Wein and D.A. MacLean (eds.), The Role of Fire in Northern Circumpolar Ecosystems. Wiley \& Sons, London.

Gara, R.I., Littke, W.R., Agee, J.K., Geiszler, D.R., Stuart, J.D., Driver, C.H. 1985. Influence of fires, fungi, and mountain pine beetles on development of a lodgepole pine forest in south-central Oregon, pp. 153-162. In D.M. Baumgartner, R.G. Krebill, J.T. Arnott, and G.F. Weetman (eds.), Lodgepole Pine: The Species and its Management. Washinton State University Cooperative Extension Service, Pullman, WA.

Gara, R.I., Agee, J.K., Littke, W.R., Geiszler, D.R., 1986. Fire wounds and beetle scars. J. Forestry 84:47-50.

Geiszler, D.R., Gara, R.I., Driver, C.H., Gallucci, V.F., Martin, R.E. 1980. Fire, fungi, and beetle influences on a lodgepole pine ecosystem in south-central Oregon. Oecologia 46:239-243.

Gruell, G.E. 1985. Indian fires in the interior west: A widespread influence, pp. 68-74. In J.E. Lotan, B.M. Kilgore, W.C. Fischer, and R.W. Mutch (technical coords.), Proceedings: Symposium and Workshop on Wilderness Fire. USDA, Forest Service, General Technical Report INT-182.

Habeck, J.R. 1974. Forests, fuels and fire in the Selway-Bitterroot Wilderness, Idaho, pp. 305-353. In: Proceedings, Tall Timbers Fire Ecology Conference, Missoula, MT.

Habeck, J.R. 1985. Impact of fire suppression on forest succession and fuel accumulations 
in long-fire-interval wilderness habitat types, pp. 110-118. In J.E. Lotan, B.M. Kilgore, W.C. Fischer, and R.W. Mutch (technical coords.), Proceedings: Symposium and Workshop on Wilderness Fire. USDA, Forest Service, General Technical Report INT-182.

Harris, L.D. 1984. The Fragmented Forest: Island Biogeography Theory and the Preservation of Biotic Diversity. University of Chicago Press, Chicago.

Hawksworth, F.G. 1975. Dwarf mistletoe and its role in lodgepole pine ecosystems, pp. 342-358. In D.M. Baumgartner (ed.), Management of Lodgepole Pine Ecosystems. Washington State University Cooperative Extension Service, Pullman, WA.

Hawksworth, F.G., Lister, C.K., Cahill, D.B., 1983. Phloem thickness in lodgepole pine: Its relationship to dwarf mistletoe and Mountain pine beetle. Environ. Entomo. $12: 1447-1448$

Heinselman, M.L. 1973. Fire in the virgin forests of the Boundary Waters Canoe Area, Minnesota. Quatern. Res. 3: 329-382.

Heinselman, M.L. 1981a. Fire and succession in the conifer forests of Northern North America, pp. 374-405. In D.C. West, H.H. Shugart, and D. B. Botkin (eds.), Forest Succession: Concepts and Application. Springer-Verlag, New York.

Heinselman, M.L. 1981b. Fire intensity and frequency as factors in the distribution and structure of northern ecosystems, pp. 7-57. In H.A. Mooney, T.M. Bonnicksen, N.L. Christensen, J.E. Lotan, and W.A. Reiners (eds.), Fire Regimes and Ecosystem Properties. United States Department of Agriculture, Forest Service, General Technical Report WO-26.

Heinselman, M.L. 1985. Fire regimes and management options in ecosystems with large high-intensity fires, pp. 101-109. In J.E. Lotan, B.M. Kilgore, W.C. Fischer, and R.W. Mutch (technical coords.), Proceedings: Symposium and Workshop on Wilderness Fire. USDA, Forest Service, General Technical Report INT-182.

Hemstrom, M.A. 1979. A recent disturbance history of forest ecosystems at Mount Rainier National Park. Doctoral dissertation, Oregon State University, Corvallis, OR.

Hett, J. 1971. Landscape changes in east Tennessee and a simulation model which describes these changes for three counties. Ecological Sciences Division Publication 414 (ORNL-IBP-71-8), Oak Ridge National Laboratory, Oak Ridge, TN.

Johnson, P.C., Denton, R.E. 1975. Outbreaks of western spruce budworm in the American northern Rocky Mountains from 1922-1971. U.S.D.A., Forest Service, General Technical Report INT-20.

Johnson, W.C. 1977. A mathematical model of forest succession and land use for the North Carolina piedmont. Bull. Torrey Botan. Club 104:334-346.

Kessell, S.R. 1976a. Gradient modeling: A new approach to fire modeling and wilderness resource management. J. Environ. Management 1:39-48.

Kessell, S.R. 1976b. Wildland inventories and fire modeling by gradient analysis in Glacier National Park, pp. 115-162. In: Proceedings, Tall Timber Fire Ecology Conference, Missoula, Montana. Tall Timbers Research Station, Tallahasse, FL.

Kessell, S.R. 1979. Gradient Modeling: Resource and Fire Management. Springer-Verlag, New York.

Kilgore, B.M. 1981. Fire in ecosystem distribution and structure: Western forests and scrublands, pp. 58-89. In H.A. Mooney, T.M. Bonnicksen, N.L. Christensen, J.E. Lotan, and W.A. Reiners (eds.), Fire Regimes and Ecosystem Properties. United States Department of Agriculture, Forest Service, General Technical Report WO26.

Komarek, Sr., E.V. 1964. The natural history of lightning, pp. 139-183. In: Proceedings, Third Annual Tall Timbers Fire Ecology Conference, Tallahassee, FL.

Kourtz, P. 1967. Lightning behavior and lightning fires in Canadian forests. Department of Forestry and Rural Development, Ottawa, Canada. Departmental publ. No. 1179.

Kozlowski, T.T., Ahlgren, C.E. (eds.) 1974. Fire and Ecosystems. Academic Press, New York. 
Krawielitzki, V.S., Vit'e, J.P., Sturm, U., Francke, W. 1983. Interactions between resin flow and subcortically feeding Coleoptera. Z. Angew. Entomol. 96:140-146.

Leaf, C.F. 1975. Watershed management in the Rocky Mountain subalpine zone: The status of our knowledge. USDA, Forest Service, Research Paper RM-137.

Leopold, A.S. 1933. Game Management. Scribners, New York.

Lotan, J.E., Kilgore, B.M., Fischer, W.C., Mutch, R.W. (technical coords.), 1985a. Proceedings: Symposium and Workshop on Wilderness Fire. USDA. Forest Service, General Technical Report INT-182.

Lotan, J.E., Brown, J.K., Neuenschwander, L.F. 1985b. Role of fire in lodgepole pine forests, pp. 133-152. In D.M. Baumgartner, R.G. Krebill, J.T. Arnott, and G.F. Weetman (eds.), Lodgepole Pine: The Species and its Management. Washington State University Cooperative Extension Service, Pullman, WA.

Matson, P.A., Waring, R.H. 1984. Effects of nutrient and nitrogen limitation on mountain hemlock: susceptibility to laminated root rot. Ecology 65:1517-1524.

McCune, B. 1983. Fire frequency reduced by two orders of magnitude in the Bitterroot Canyon, Montana. Can. J. Forest Res. 13:212-218.

McDonald, G.I. 1981. Differential defoliation of neighboring Douglas fir trees by western spruce budworm. USDA, Forest Service, Research Note INT-306.

Minnich, R.A. 1983. Fire mosaics in southern California and northern Baja California. Science 219:1287-1294.

Mooney, H.A., Bonnicksen, T.M., Christensen, N.L., Lotan, J.E., Reiners, W.A. (eds.) 1981. Fire Regimes and Ecosystem Properties. United States Department of Agriculture, Forest Service, General Technical Report WO-26.

Mutch, R.W. 1970. Wildland fires and ecosystems-a hypothesis. Ecology 51:10461051.

Peterman, R.M. 1978. The ecological role of mountain pine beetle in lodgepole pine forests, pp. 16-26. In D.L. Kibbee, A.A. Berryman, G.D. Amman, and R.W. Stark (eds.), Theory and Practice of Mountain Pine Beetle Management in Lodgepole Pine Forests. Forest, Wildlife, and Range Experiment Station, University of Idaho. Moscow, ID.

Pickett, S.T.A. 1976. Succession: An evolutionary interpretation. Am. Naturalist 110:107-119.

Pickett, S.T.A., Thompson, J.N. 1978. Patch dynamics and the design of nature preserves. Biol. Conserv. 13:27-37.

Pickett, S.T.A., White, P.S. 1985. Patch dynamics: A synthesis, pp. 371-384. In S.T.A. Pickett and P.S. White (eds.), The Ecology of Natural Disturbance and Patch Dynamics. Academic Press, New York.

Plummer, F.G. 1912. Lightning in relation to forest fires. United States Department of Agriculture, Forest Service, Bulletin No. 111.

Pyne, S.J. 1984. Introduction to Wildland Fire. Wiley \& Sons, New York.

Raffa, K.F., Berryman, A.A. 1982. Physiological differences between lodgepole pines resistant and susceptible to the Mountain pine beetle and associated microorganisms. Environ. Entomol. 11:486-492.

Reiners, W.A., Lang, G.E. 1979. Vegetational patterns and processes in the balsam fir zone, White Mountains, New Hampshire. Ecology 60:403-417.

Romme, W.H. 1982. Fire history and landscape diversity in Yellowstone National Park. Ecolog. Monogr. 52:199-221.

Romme, W.H., Knight, D.H. 1981. Fire frequency and subalpine forest succession along a topographic gradient in Wyoming. Ecology 62:319-326.

Romme, W.H., Knight, D.H. 1982. Landscape diversity: The concept applied to Yellowstone Park. BioSci. 32:664-670.

Romme, W.H., Knight, D.H., Yavitt, J.B. 1986. Mountain pine beetle outbreaks in the Central Rocky Mountains: Effects on primary productivity. Am. Naturalist 127:484494.

Rothermel, R.C. 1983. How to predict the spread and intensity of forest and range fires. USDA, Forest Service, General Technical Report INT-143. 
Rowe, J.S. 1979. Large fires in the large landscapes of the north, pp. 8-32. In: Proceedings, Symposiam on Fire Management in the Northern Environment. USDI, Bureau of Land Management, Alaska State Office.

Royama, T. 1984. Population dynamics of the spruce budworm Choristoneura fumiferana. Ecolog. Monogr. 54:429-462.

Rundel, P.W. 1981. Structural and chemical components of flammability, pp. 183-207. In H.A. Mooney, T.M. Bonnicksen, N.L. Christensen, J.E. Lotan, and W.A. Reiners (eds.), Fire Regimes and Ecosystem Properties. United States Department of Agriculture, Forest Service, General Technical Report WO-26.

Schowalter, T.D., Coulson, R.N., Crossley, Jr., D.A. 1981. Role of southern pine beetle and fire in maintenance of structure and function of the southeastern coniferous forest. Environ. Entomol. 10:821-825.

Schowalter, T.D. 1985. Adaptations of insects to disturbance, pp. 235-252. In S.T.A. Pickett and P.S. White (eds.), The Ecology of Natural Disturbance and Patch Dynamics. Academic Press, New York.

Schmid, J.M., Hinds, T.E. 1974. Development of spruce-fir stands following spruce beetle outbreaks. USDA, Forest Service, Research Paper RM-131.

Shugart, H.H., Seagle, S.W. 1985. Modeling forest landscapes and the role of disturbance in ecosystems and communities, pp. 353-368. In S.T.A. Pickett and P.S. White (eds.), The Ecology of Natural Disturbance and Patch Dynamics. Academic Press, New York.

Sprugel, D.G. 1976. Dynamic structure of wave-regenerated Abies balsamea forests in the northeastern United States. J. Ecology 64:889-911.

Stocks, B.J. 1985. Forest fire behavior in spruce budworm-killed balsam fir, pp. 188199. In C.J. Sanders, R.W. Stark, E.J. Mullins, and J. Murphy (eds.), Recent Advances in Spruce Budworm Research. Proceedings of the CANUSA Spruce Budworm Research Symposium, Bangor, ME, September 1984. Canadian Forest Service, Ottawa, Ontario.

Swain, A.M. 1980. Landscape patterns and forest history in the Boundary Waters Canoe Area, Minnesota. A pollen study from Hug Lake. Ecology 61:747-754.

Taylor, A.R. 1973. Ecological aspects of lightning in forests, pp. 455-482. In: Proceedings, Tall Timbers Fire Ecology Conference. Tall Timbers Research Station, Tallahassee, FL.

Thomas, J.W., Miller, R.J., Black, H., Rodiek, J.E., Maser, C. 1976. Guidelines for maintaining and enhancing wildlife habitat in forest management in the Blue Mountains of Oregon and Washington, pp. 452-476. In: Transactions, 4Ist North American Wildlife and Natural Resources Conference.

Tinnin, R.O. 1984. The effect of dwarf mistletoe on forest community ecology, pp. 117122. In F.G. Hawksworth and R.F. Scharpf (eds.), Biology of Dwarf Mistletoes: Proceedings of the Symposium. United States Department of Agriculture, Forest Service, General Technical Report RM-111.

Tkacz, B.M., Schmitz, R.F. 1986. Association of an endemic mountain pine beetle population with lodgepole pine infected by Armillaria root disease in Utah. USDA, Forest Service, Research Note INT-353.

van Wagner, C.E. 1977. Conditions for the start and spread of crown fire. Can. J. Forest Res. 7:23-34.

van Wagner, C.E. 1978. Age class distribution and the forest fire cycle. Can.J. Forest Res. 8:220-227.

van Wagner, C.E. 1983. Fire behaviour in northern conifer forests and shrublands, pp. 65-80. In R.W. Wein and D.A. MacLean (eds.), The Role of Fire in Northern Circumpolar Ecosystems. Wiley \& Sons, New York.

van Wagner, C.E. 1985. Does nature really care who starts the fire?, pp. 98-100. In J.E. Lotan, B.M. Kilgore, W.C. Fischer, and R.W. Mutch (technical coords.), Proceedings: Symposium and Workshop on Wilderness Fire. USDA, Forest Service, General Technical Report INT-182. 
van Wagtendonk, J.W. 1985. Fire suppression effect on fuels and succession in shortfire-interval wilderness landscapes, pp. 119-126. In J.E. Lotan, B.M. Kilgore, W.C. Fischer, and R.W. Mutch (technical coords.), Proceedings: Symposium and Workshop on Wilderness Fire. USDA, Forest Service, General Technical Report INT-182.

Vankat, J.L. 1985. General patterns of lightning ignitions in Sequoia National Park, California, pp. 408-411. In J.E. Lotan, B.M. Kilgore, W.C. Fischer, and R.W. Mutch (technical coords.), Proceedings: Symposium and Workshop on Wilderness Fire. USDA, Forest Service, General Technical Report INT-182.

Waring, R.H., Pitman, G.B. 1983. Physiological stress in lodgepole pine as a precursor for Mountain pine beetle attack. Zeitschrift fur Angewendte Entomologie 96:265270 .

Waring, R.H., Pitman, G.B. 1985. Modifying lodgepole pine stands to change susceptibility to mountain pine beetle attack. Ecology 66:889-897.

Waring, R.H., Schlesinger, W.H. 1985. Forest Ecosystems: Concepts and Management. Academic Press, New York.

Webb, III, T. 1981. The past 11,000 years of vegetational change in eastern North America. BioSci 31:501-506.

Wein, R.W., MacLean, D.A. 1983. The Role of Fire in Northern Circumpolar Ecosystems. Wiley \& Sons, New York.

Weinstein, D.A., Shugart, H.H. 1983. Ecological modeling of landscape dynamics, pp. 29-45. In H. Mooney and M. Godron (eds.), Disturbance and Ecosystems. SpringerVerlag, New York.

Wicker, E.F., Leaphart, C.D. 1976. Fire and dwarf mistletoe (Arceuthobium spp.) relationships in the northern Rocky Mountains, pp. 279-298. In: Proceedings, 1974 Tall Timbers Fire Ecology Conference. Tall Timbers Research Station, Tallahassee, FL.

Wright, Jr., H.E. 1974. Landscape development, forest fires, and wilderness management. Science 186:487-495.

Wright, Jr., H.E., Heinselman, M.L. 1973. The ecological role of fire in natural coniferous forests of western and northern North America. Quatern. Res. 3:319-328.

Zimmerman, G.T., Laven, R.D. 1984. Ecological interrelationships of dwarf mistletoe and fire in lodgepole pine forests, pp. 123-131. In F.G. Hawksworth and R.F. Scharpf (eds.), Biology of Dwarf Mistletoes: Proceedings of a Symposium. USDA, Forest Service, General Technical Report RM-111. 


\title{
Monica Goigel Turner \\ Editor
}

\section{Landscape Heterogeneity and Disturbance}

\author{
Contributors
}

D.J. Bogucki, F.H. Bormann, E.O. Box, S.P. Bratton, R. Dolan, C.P. Dunn, R.T.T. Forman, G.K. Gruendling, G.R. Guntenspergen, T.D. Hayes, D.H. Knight, L.A. Leitner, V. Meentemeyer, D. Morrison, J.I. Nassauer, W.E. Odum, W.L. Pace, III, M.M. Remillard, D.H. Riskind, P.G. Risser, D.M. Sharpe, T.J. Smith, III, F. Stearns, M.G. Turner, R. Westmacott

With 56 Illustrations
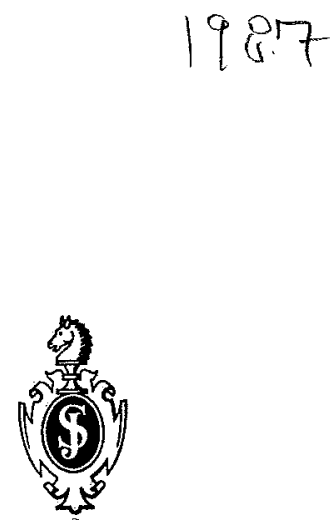

Springer-Verlag New York Berlin Heidelberg

London Paris Tokyo 
Monica Goigel Turner

Institute of Ecology

University of Georgia

Athens, Georgia 30602

USA

Library of Congress Cataloging-in-Publication Data

Landscape heterogeneity and disturbance.

(Ecological studies; 64)

Includes index.

1. Landscape protection. 2. Ecology. 1. Turner,

Monica Goigel. II. Title.

QH75.L29 $1987 \quad 333.73 \quad 87-4418$

(C) 1987 by Springer-Verlag New York Inc.

All rights reserved. This work may not be translated or copied in whole or in part without the written permission of the publisher (Springer-Verlag, 175 Fifth Avenue, New York, New York 10010, USA), except for brief excerpts in connection with reviews or scholarly analysis. Use in connection with any form of information storage and retrieval, electronic adaptation, computer software, or by similar or dissimilar methodology now known or hereafter developed is forbidden. The use of general descriptive names, trade names, trademarks, etc. in this publication, even if the former are not especially identified, is not to be taken as a sign that such names, as understood by the Trade Marks and Merchandise Marks Act, may accordingly be used freely by anyone.

Although the research described in this article has been funded wholly or in part by the United States Environmental Protection Agency (EPA) through Interagency Agreement Number 40-74078 to the U.S. Department of Energy, it has not been subjected to EPA review and therefore does not necessarily reflect the views of EPA and no official endorsement should be inferred.

Typeset by David Seham Associates, Metuchen, New Jersey.

Printed and bound by Quinn-Woodbine Inc., Woodbine, New Jersey.

Printed in the United States of America.

987654321

ISBN 0-387-96497-5 Springer-Verlag New York Berlin Heidelberg ISBN 3-540-96497-5 Springer-Verlag Berlin Heidelberg New York 